\title{
Article \\ A Mitochondria-Penetrating Peptide Exerts Potent Anti-Plasmodium Activity and Localizes at Parasites' Mitochondria
}

\author{
Sangdao Somsri ${ }^{1}$, Mathirut Mungthin ${ }^{2}$, Natthaporn Klubthawee ${ }^{1}$, Poom Adisakwattana ${ }^{3}$, \\ Warunee Hanpithakpong ${ }^{4}\left(\mathbb{D}\right.$ and Ratchaneewan Aunpad ${ }^{1, *}$
}

check for updates

Citation: Somsri, S.; Mungthin, M.; Klubthawee, N.; Adisakwattana, P.; Hanpithakpong, W.; Aunpad, R. A Mitochondria-Penetrating Peptide Exerts Potent Anti-Plasmodium Activity and Localizes at Parasites' Mitochondria. Antibiotics 2021, 10, 1560. https://doi.org/10.3390/ antibiotics 10121560

Academic Editor:

Jesus Simal-Gandara

Received: 26 October 2021

Accepted: 14 December 2021

Published: 20 December 2021

Publisher's Note: MDPI stays neutral with regard to jurisdictional claims in published maps and institutional affiliations.

Copyright: (c) 2021 by the authors. Licensee MDPI, Basel, Switzerland. This article is an open access article distributed under the terms and conditions of the Creative Commons Attribution (CC BY) license (https:// creativecommons.org/licenses/by/ $4.0 /)$.
1 Graduate Program in Biomedical Sciences, Faculty of Allied Health Sciences, Thammasat University, Pathum Thani 12120, Thailand; ss_sangdao@hotmail.com (S.S.); p.natthaporn.k@gmail.com (N.K.)

2 Department of Parasitology, Phramongkutklao College of Medicine, Bangkok 10400, Thailand; mathirut@pmk.ac.th

3 Department of Helminthology, Faculty of Tropical Medicine, Mahidol University, Bangkok 10400, Thailand; poom.adi@mahidol.edu

4 Mahidol Oxford Tropical Medicine Research Unit, Faculty of Tropical Medicine, Mahidol University, Bangkok 10400, Thailand; Warunee@tropmedres.ac

* Correspondence: aratchan@tu.ac.th; Tel.: +662-986-9213-9 (ext. 7210)

\begin{abstract}
Mitochondria are considered a novel drug target as they play a key role in energy production and programmed cell death of eukaryotic cells. The mitochondria of malaria parasites differ from those of their vertebrate hosts, contributing to the drug selectivity and the development of antimalarial drugs. $\left(\mathrm{F}_{\mathrm{x}} \mathrm{r}\right)_{3}$, a mitochondria-penetrating peptide or MPP, entered malaria-infected red cells without disrupting the membrane and subsequently killed the blood stage of P. falciparum parasites. The effects were more potent on the late stages than on the younger stages. Confocal microscopy showed that the $\left(\mathrm{F}_{\mathrm{x}} \mathrm{r}\right)_{3}$ intensely localized at the parasite mitochondria. $\left(\mathrm{F}_{\mathrm{x}} \mathrm{r}\right)_{3}$ highly affected both the lab-strain, chloroquine-resistant $\mathrm{K} 1$, and freshly isolated malaria parasites. $\left(\mathrm{F}_{\mathrm{x}} \mathrm{r}\right)_{3}(1 \mathrm{ng} / \mathrm{mL}$ to $10 \mu \mathrm{g} / \mathrm{mL}$ ) was rarely toxic towards various mammalian cells, i.e., mouse fibroblasts (L929), human leukocytes and erythrocytes. At a thousand times higher concentration $(100 \mu \mathrm{g} / \mathrm{mL})$ than that of the antimalarial activity, cytotoxicity and hemolytic activity of $\left(\mathrm{F}_{\mathrm{x}} \mathrm{r}\right)_{3}$ were observed. Compared with the known antimalarial drug, atovaquone, $\left(\mathrm{F}_{\mathrm{x}} \mathrm{r}\right)_{3}$ exhibited more rapid killing activity. This is the first report on antimalarial activity of $\left(\mathrm{F}_{\mathrm{X}} \mathrm{r}\right)_{3}$, showing localization at parasites' mitochondria.
\end{abstract}

Keywords: mitochondria-penetrating peptide; Plasmodium falciparum; antimalarial; localization

\section{Introduction}

Malaria remains a life-threatening disease, causing millions of cases worldwide with around 405,000 deaths annually [1]. There are five different species of the Plasmodium parasite causing human malaria, namely Plasmodium falciparum, Plasmodium vivax, Plasmodium ovale, Plasmodium malariae and Plasmodium knowlesi. The most severe form is caused by P. falciparum, as it often leads to death and can be fatal not long after the first symptoms [2]. The increase and spread of multidrug-resistant $P$. falciparum have become major challenges to malaria treatment and are correlated with increases in morbidity and mortality in many malaria-endemic countries [1]. In response to this harsh predicament, artemisinin-based combination therapies (ACTs) have been recommended and widely established in malariaendemic regions. Unfortunately, the recent Global Malaria Programme report pointed to artemisinin and ACT resistance causing significant delays in parasite clearance [3]. The development of novel antimalarial drugs and more effective therapy is urgently needed.

The Plasmodium mitochondrion contains the smallest eukaryotic mtDNA (6-kb), encoding only three genes for proteins and highly fragmented rRNA genes [4]. The differences in the mitochondria of malaria parasites from those of their vertebrate hosts allow for 
drug selectivity and potential targets for antimalarial drug development. Atovaquone is well known for malaria treatment, acts on the malaria mitochondrion, and has a very low frequency of side effects [5]. Even though the parasite has developed resistance to atovaquone, it maintains high efficiency when used in combination with proguanil for prophylaxis against malaria in endemic areas [6].

In the past ten years, it has been shown that several peptides can act on malarial parasites. The small linear angiotensin I and II-derived peptides exhibit antiplasmodial activity against the blood stage of both avian P. gallinaceum and P. falciparum [7,8]. Symplostatin 4 (Sym4), a marine-derived peptide, kills P. falciparum at nanomolar concentrations, generating a swollen food vacuole and inhibiting the initial stage of hemoglobin degradation [9]. Moreover, several host defense or antimicrobial peptides have been reported to disturb malaria homeostasis by disrupting parasite cellular membranes or interfering with key processes of parasite metabolism, and surprisingly kill the parasite [10,11]. One example is dermaseptin and its truncated derivatives, which exert anti-P. falciparum activity in the micromolar range by permeabilization of the cell membrane [12,13]. These antiplasmodial peptides, both natural and synthetic molecules, vary in size, charge, amino acid composition, hydrophobicity and secondary structure, and some of them appear to act selectively on infected erythrocytes and/or intraerythrocytic parasite membranes [11]. This implies that membrane-active peptides, such as cell-penetrating peptides (CPPs) or mitochondriapenetrating peptides (MPPs), which can translocate into cells without membrane damage, may be novel compounds for development as antimalarial agents.

Mitochondria-penetrating peptides or MPPs are a class of peptides with the ability to enter human cells and specifically target the mitochondria. The combination of two major characteristics, being cationic and lipophilic, drives the permeation of MPPs through the hydrophobic mitochondrial membrane [14]. The mechanism of MPPs depends on their concentration. The peptide binds to the membrane's outer leaflet at low concentrations while crossing the hydrophobic bilayer and diffuses into both leaflets at high concentrations. Moreover, MPPs can cross to the inner leaflet without disturbing the lamellarity and transmembrane, which offer adequate energy for peptides to cross the hydrophobic core [15]. The characteristics and actions of MPPs lead to antimicrobial or antimalarial activities. One such short peptide, (L-cyclohexyl alanin-D-arginine) ${ }_{3}$ or $\left(\mathrm{F}_{\mathrm{x}} \mathrm{r}\right)_{3}$, exhibited efficient and promising cell penetration and mitochondrial localization [14]. The objective of this study was to determine the antimalarial activity of $\left(\mathrm{F}_{\mathrm{x}} \mathrm{r}\right)_{3}$ and elucidate its localization in P. falciparum. Our findings suggest that $\left(\mathrm{F}_{\mathrm{x}} \mathrm{r}\right)_{3}$ might be developed as a new antimalarial agent for use alone or in combination with current antimalarial agents.

\section{Results}

\section{1. $\left(F_{x} r\right)_{3}$ Showed No Toxicity toward L929 Mouse Fibroblast Cells}

The cytotoxicity activity of $\left(\mathrm{F}_{\mathrm{x}} \mathrm{r}\right)_{3}$ toward L929 mouse fibroblast cells was determined using the MTT (3-(4,5-dimethylthiazol-2-yl)-2,5-diphenyltetrazolium bromide, a tetrazole) assay. As shown in Figure 1, at concentrations from $1 \mathrm{ng} / \mathrm{mL}$ to $10 \mu \mathrm{g} / \mathrm{mL},\left(\mathrm{F}_{\mathrm{x}} \mathrm{r}\right)_{3}$ showed no toxicity with cell viabilities of more than $99 \%$, which is comparable to that of the negative control (untreated cells). By contrast, at the highest concentration of $\left(\mathrm{F}_{\mathrm{x}} \mathrm{r}\right)_{3}$ tested $(100 \mu \mathrm{g} / \mathrm{mL})$, the viability of these fibroblast cells was less than $10 \%$.

\section{2. $\left(F_{x} r\right)_{3}$ Demonstrated Very Low Toxicity against Human Peripheral White and Red Blood Cells}

The toxicity of $\left(\mathrm{F}_{\mathrm{x}} \mathrm{r}\right)_{3}$ against human peripheral white blood (PBMCs) and red blood cells was determined by MTT and hemolysis assays, respectively. The results showed that the viability of human PBMCs was not significantly affected by $\left(\mathrm{F}_{\mathrm{x}} \mathrm{r}\right)_{3}$ at concentrations from $1 \mathrm{ng} / \mathrm{mL}$ to $1 \mu \mathrm{g} / \mathrm{mL}$ when compared to that of negative controls (Figure $2 \mathrm{~A}$ ). This was in accordance with the results of hemolytic activity determinations. However, at a concentration of $10 \mu \mathrm{g} / \mathrm{mL}$, there was less toxicity toward red blood cells, and this was not significantly different from that of negative controls (Figure 2B). At the highest 
concentration tested $(100 \mu \mathrm{g} / \mathrm{mL}),\left(\mathrm{F}_{\mathrm{x}} \mathrm{r}\right)_{3}$ exhibited a lethal effect on both human PBMCs and red blood cells.

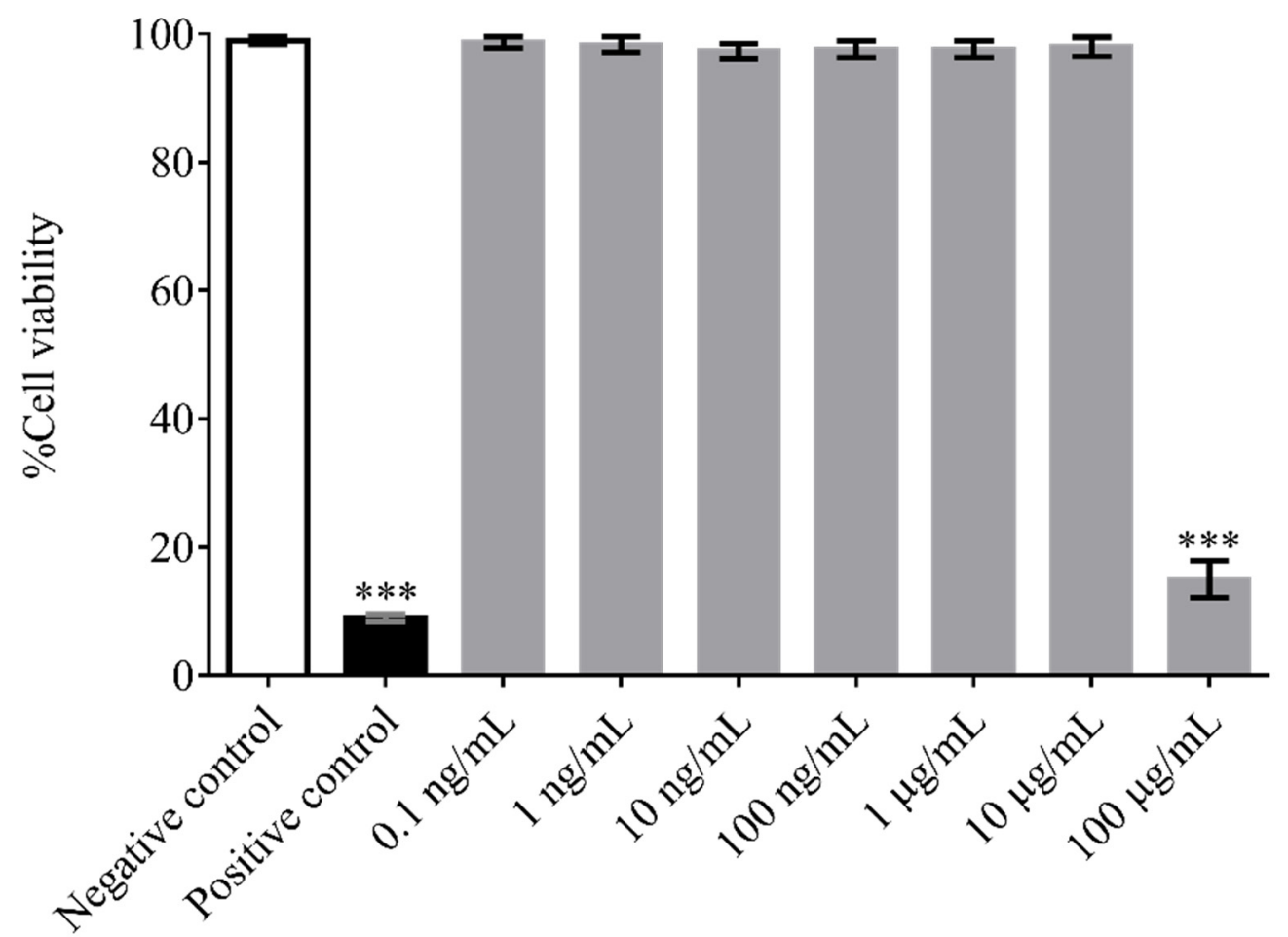

Figure 1. The viability of L929 mouse fibroblast cells after treatment with different concentrations of $\left(\mathrm{F}_{\mathrm{x}} \mathrm{r}\right)_{3}$. Data were obtained from three individual experiments. Stars indicate a significant difference compared with negative control $(p<0.05)$. Untreated cells and cells treated with $20 \%$ DMSO were used as negative and positive controls, respectively.

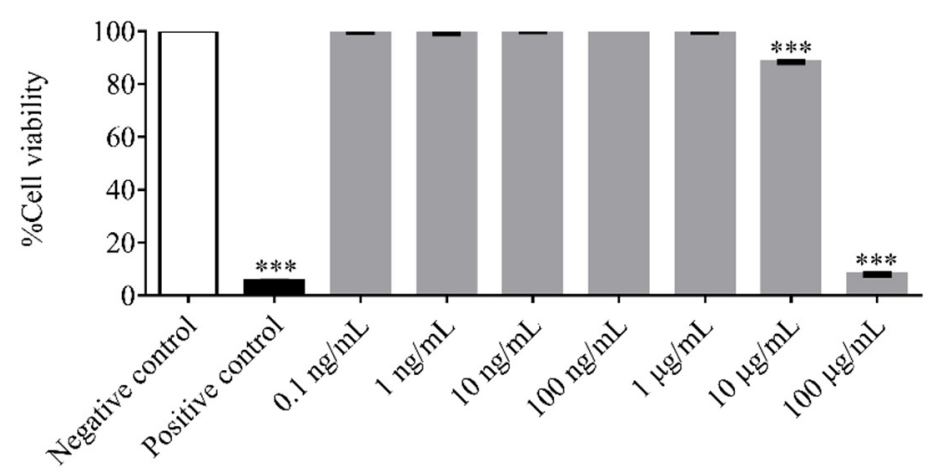

$\mathbf{A}$

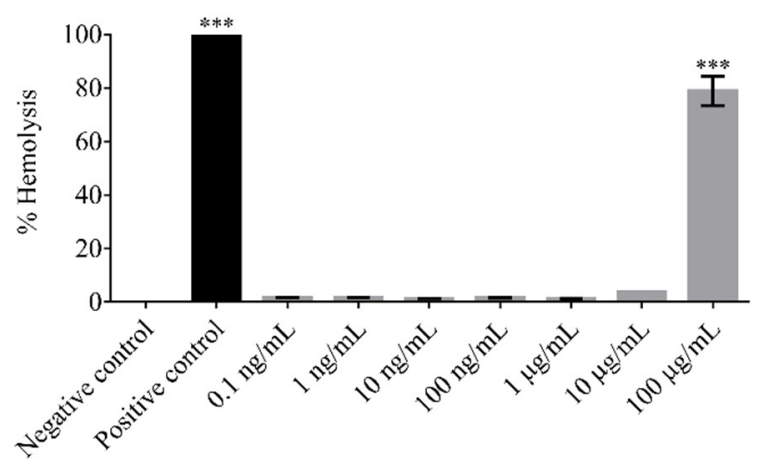

B

Figure 2. The cell viability of human PBMCs $(\mathbf{A})$ and red blood cells $(\mathbf{B})$ after treatment with $\left(\mathrm{F}_{\mathrm{x}} \mathrm{r}\right)_{3}$ at different concentrations. Data were obtained from three individual experiments. Stars indicate a significant difference compared with the negative control $(p<0.05)$.

\section{3. $\left(F_{x} r\right)_{3}$ Exhibited Antimalarial Activity in Nano Range}

Antimalarial activity of $\left(\mathrm{F}_{\mathrm{x}} \mathrm{r}\right)_{3}$ was determined against chloroquine-sensitive (3D7) and resistant (K1) strains of Plasmodium falciparum, as well as two field isolates (J1 and MR4). Due to the different forms of parasite mitochondria, the effect of $\left(F_{x} r\right)_{3}$ was evaluated in both early- and late-stage parasites (24 and $48 \mathrm{~h}$ ). $\mathrm{IC}_{50}$ was measured, and parasite morphology was observed under light microscopy. After incubation of $\left(\mathrm{F}_{\mathrm{x}} \mathrm{r}\right)_{3}$ with earlystage parasites for $24 \mathrm{~h}, \mathrm{IC}_{50}$ of strain $\mathrm{K} 1$ and $3 \mathrm{D} 7$ were 454.7 and $444.6 \mathrm{ng} / \mathrm{mL}$, respectively 
(Figure 3). Both K1 and 3D7 showed similar morphology, with rounded chromatin and large vacuoles. After $48 \mathrm{~h}$ of incubation, parasites did not develop into the trophozoite and schizont stages and displayed a large vacuole with compact chromatin. The $\mathrm{IC}_{50}$ values of $\left(\mathrm{F}_{\mathrm{x}} \mathrm{r}\right)_{3}$ against early-stage parasites after 48 -h incubation were $192.1 \mathrm{ng} / \mathrm{mL}$ and $13.24 \mathrm{ng} / \mathrm{mL}$ for strains $\mathrm{K} 1$ and $3 \mathrm{D} 7$, respectively. The $\mathrm{IC}_{50}$ of $\left(\mathrm{F}_{\mathrm{x}} \mathrm{r}\right)_{3}$ against early-stage of both strains, $\mathrm{K} 1$ and 3D7, at 24-h incubation was significantly different from that after 48-h incubation $(p<0.001)$.

Early stage

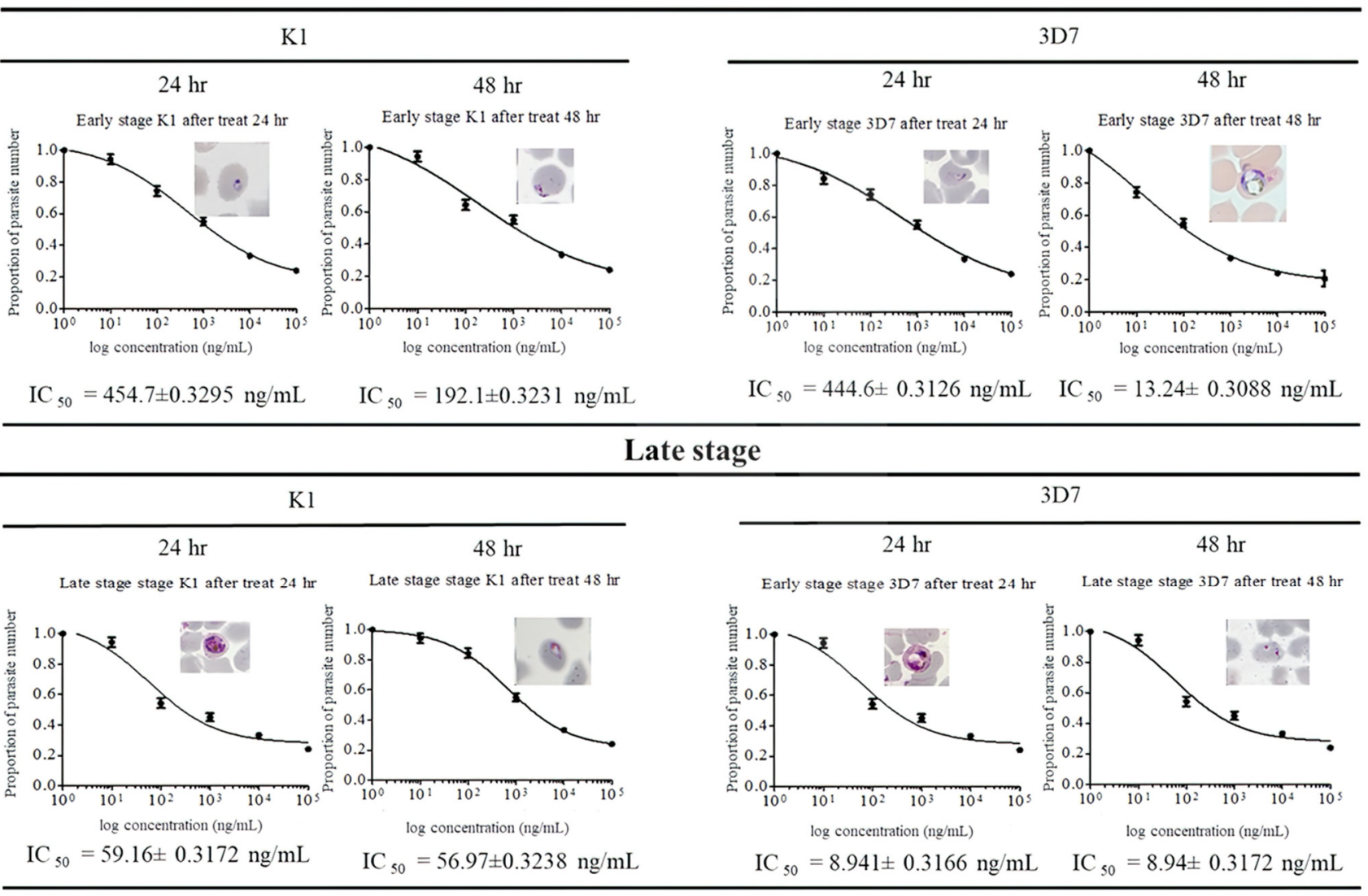

Figure 3. In vitro drug sensitivity assay of $\left(\mathrm{F}_{\mathrm{x}} \mathrm{r}\right)_{3}$ against early- and late-stage malarial parasite strains K1 and 3D7. All parasites were stained by Giemsa and observed under a light microscope $(100 \times$ oil-immersion).

After a 24-h treatment of $\left(\mathrm{F}_{\mathrm{x}} \mathrm{r}\right)_{3}$ toward late-stage parasites, the $\mathrm{IC}_{50}$ 's were 59.16 and $8.94 \mathrm{ng} / \mathrm{mL}$ for strains K1 and 3D7, respectively. Microscopy revealed that the parasites did not develop into the mature schizont stage and showed a large vacuole with compact chromatin. After continuing incubation to $48 \mathrm{~h}$, the $\mathrm{IC}_{50}$ of $\left(\mathrm{F}_{\mathrm{x}} \mathrm{r}\right)_{3}$ toward strain $3 \mathrm{D} 7 \mathrm{was}$ not significantly different from that after the 24-h incubation $(p=0.997)$. On the contrary, the $\mathrm{IC}_{50}$ of $24-\mathrm{h}$ incubation of strain $\mathrm{K} 1$ was significantly different from that after $48-\mathrm{h}$ incubation $(p=0.001)$. The morphology of parasites after a 48-h incubation (under light microscopy) was of atypical rings with compact chromatin. By statistical analysis of both strains, the $\mathrm{IC}_{50}$ of $\left(\mathrm{F}_{\mathrm{x}} \mathrm{r}\right)_{3}$ showed significant differences between early- and late-stages, and also 24- and 48-h incubations $(p<0.001)$.

The antimalarial activity of $\left(\mathrm{F}_{\mathrm{x}} \mathrm{r}\right)_{3}$ against two field isolates, J1 and MR4, was determined with both early- and late-stage parasites ( 24 and $48 \mathrm{~h}$ ), as shown in Table 1 . After $48 \mathrm{~h}$ of incubation of both early- and late-stage parasites with $\left(\mathrm{F}_{\mathrm{x}} \mathrm{r}\right)_{3}$, the $\mathrm{IC}_{50}$ of both field isolated strains were significantly lower than those at $24 \mathrm{~h}$. By statistical analysis, the $\mathrm{IC}_{50}$ of $\left(\mathrm{F}_{\mathrm{x}} \mathrm{r}\right)_{3}$ showed significant differences between early- and late-stage, and also 24- and 48-h incubations $(p<0.001)$. 
Table 1. In vitro drug sensitivity assay of $\left(\mathrm{F}_{\mathrm{x}} \mathrm{r}\right)_{3}$ against early- and late-stage field isolated malarial parasites.

\begin{tabular}{cccc}
\hline \multirow{2}{*}{ Strain } & \multicolumn{2}{c}{ IC $_{\mathbf{5 0}}$ (ng/mL) } \\
\cline { 3 - 4 } & & 24 h Incubation & $\mathbf{4 8} \mathbf{~ h ~ I n c u b a t i o n}$ \\
\hline \multirow{2}{*}{ Early-Stage } & $\mathrm{J} 1$ & $426.2 \pm 0.42$ & $116.0 \pm 0.44$ \\
& $\mathrm{MR} 4$ & $804.1 \pm 0.42$ & $51.86 \pm 0.42$ \\
Late-stage & $\mathrm{J} 1$ & $24.94 \pm 0.42$ & $9.33 \pm 0.38$ \\
& $\mathrm{MR} 4$ & $113.2 \pm 0.44$ & $33.26 \pm 0.41$ \\
\hline
\end{tabular}

\section{4. $\left(F_{x} r\right)_{3}$ Localized at Parasite's Mitochondria}

The localization of $\left(\mathrm{F}_{\mathrm{x}} \mathrm{r}\right)_{3}$ was observed in strain $\mathrm{K} 1$ under confocal microscopy using $\left(\mathrm{F}_{\mathrm{x}} \mathrm{r}\right)_{3}$ linked with TAMRA dye or TM- $\left(\mathrm{F}_{\mathrm{x}} \mathrm{r}\right)_{3}$. The parasite's nucleus and mitochondria were stained with fluorescence dye Hoechst 33,342 and mitotracker green, respectively. Hoechst 33,342 was used to stain the parasite nucleus demonstrating a live malarial parasite, while active mitochondria were stained with mitotracker green. As shown in Figure 4A, the schizont stage of strain K1 displayed a deep blue color in the middle of the cell, while light staining was observed in ring and trophozoite stages representing living parasite cells. By observing with mitotracker green, TM- $\left(\mathrm{F}_{\mathrm{x}} \mathrm{r}\right)_{3}$ showed localization of $\left(\mathrm{F}_{\mathrm{x}} \mathrm{r}\right)_{3}$ at the mitochondria of the cell. Late-stage parasites (trophozoite and schizont) displayed a higher intensity of TM- $\left(\mathrm{F}_{\mathrm{x}} \mathrm{r}\right)_{3}$ than did the ring stage.
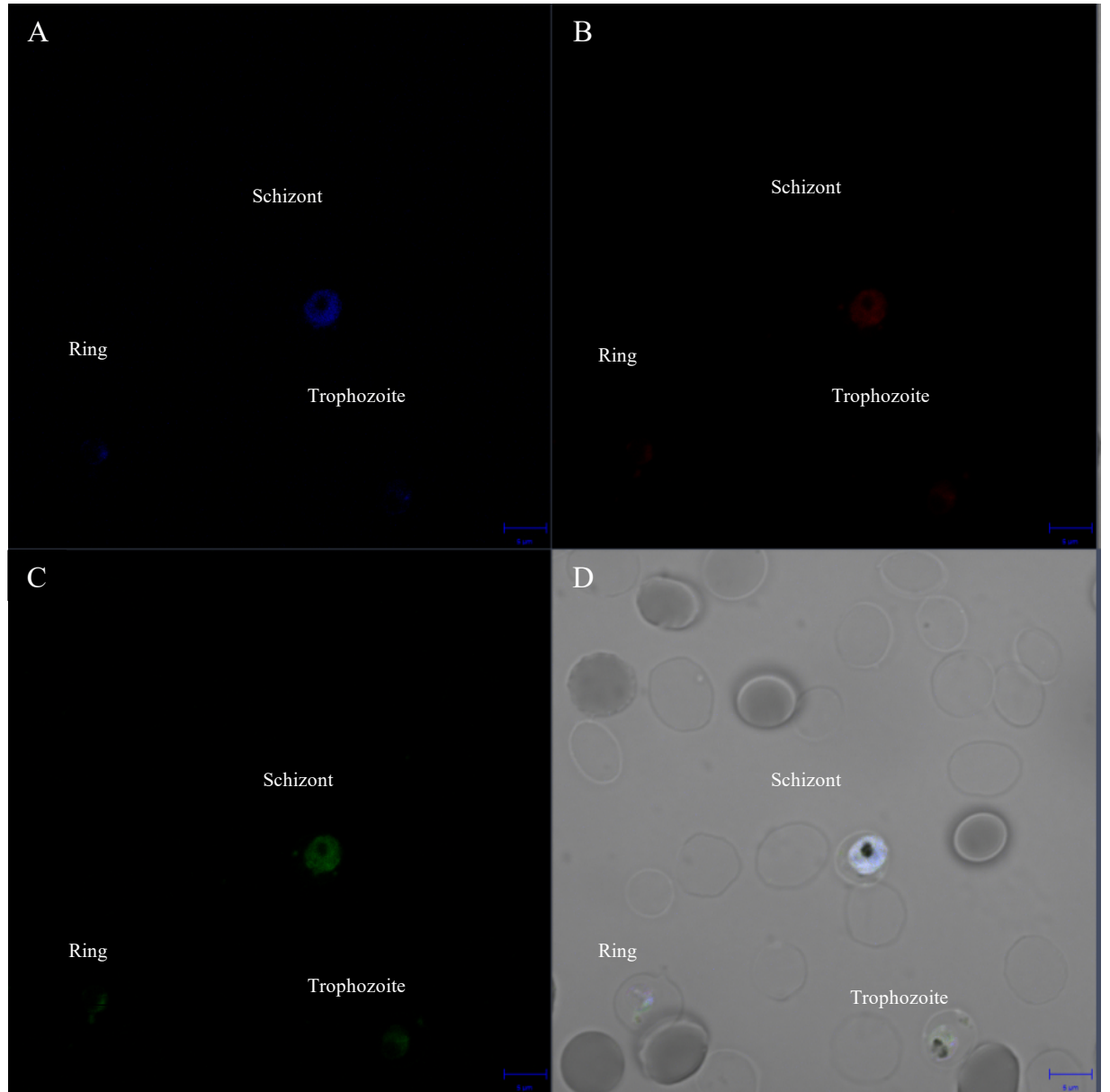

Figure 4. $\left(\mathrm{F}_{\mathrm{x}} \mathrm{r}\right)_{3}$ localization as observed by confocal microscopy. Bright field image shows all stages of the parasite living in red blood cells (D). Hoechst 33,342 (A), TM- $\left(\mathrm{F}_{\mathrm{x}} \mathrm{r}\right)_{3}(\mathbf{B})$ and mitotracker green (C) staining, representing DNA, TM- $\left(\mathrm{F}_{\mathrm{x}} \mathrm{r}\right)_{3}$ and mitochondria, respectively. 


\section{5. $\left(F_{x} r\right)_{3}$ Killed Malarial Parasites More Rapidly than ATQ}

The killing rate of malarial parasite strain $\mathrm{K} 1$ and 3D7 after incubation with $\left(\mathrm{F}_{\mathbf{x}} \mathrm{r}\right)_{3}$ was compared to that with atovaquone (ATQ) by determination of malarial cell death at $72 \mathrm{~h}$ (Figure 5). At $12 \mathrm{~h}$, there was no death of ring-stage parasites ( $0 \%$ death) in both the ATQ-treated and $\left(\mathrm{F}_{\mathrm{x}} \mathrm{r}\right)_{3}$-treated groups. Parasite death was observed at $24 \mathrm{~h}$ of incubation with $\left(\mathrm{F}_{\mathrm{x}} \mathrm{r}\right)_{3}(25 \%$ death), while ATQ-treated group showed no parasite death after $24 \mathrm{~h}$. The parasite death at 24 and $48 \mathrm{~h}$ of the $\left(\mathrm{F}_{\mathrm{x}} \mathrm{r}\right)_{3}$-treated groups were significantly different from that of ATQ-treated groups $(p<0.05)$. At $48 \mathrm{~h}$, the parasite developed to the late trophozoite and schizont stages. Parasite re-infection led to new rings after $60 \mathrm{~h}$, and the new rings were growing to a mature stage at $72 \mathrm{~h}$. The death of parasites treated with $\left(\mathrm{F}_{\mathrm{X}} \mathrm{r}\right)_{3}$ was not significantly different from that of ATQ-treated parasites after 60 and $72 \mathrm{~h}$ of incubation $(p>0.05)$.

A

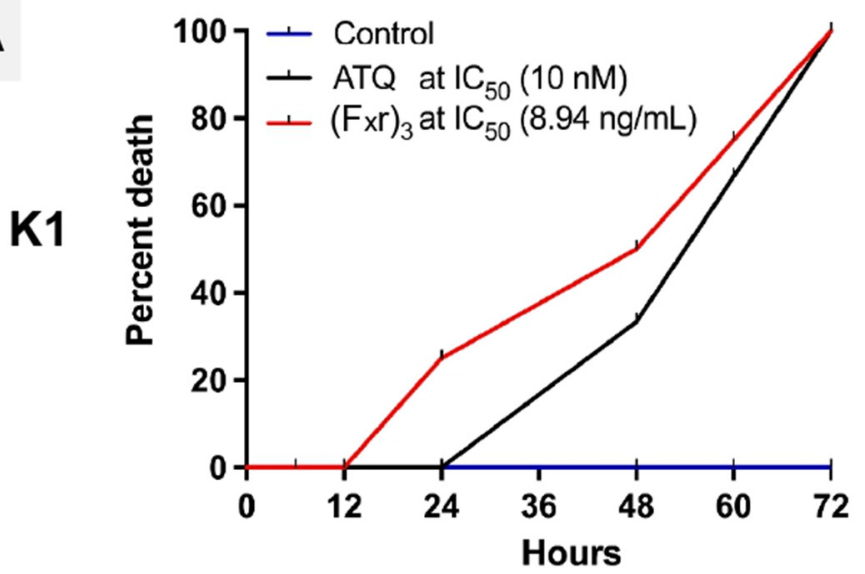

C

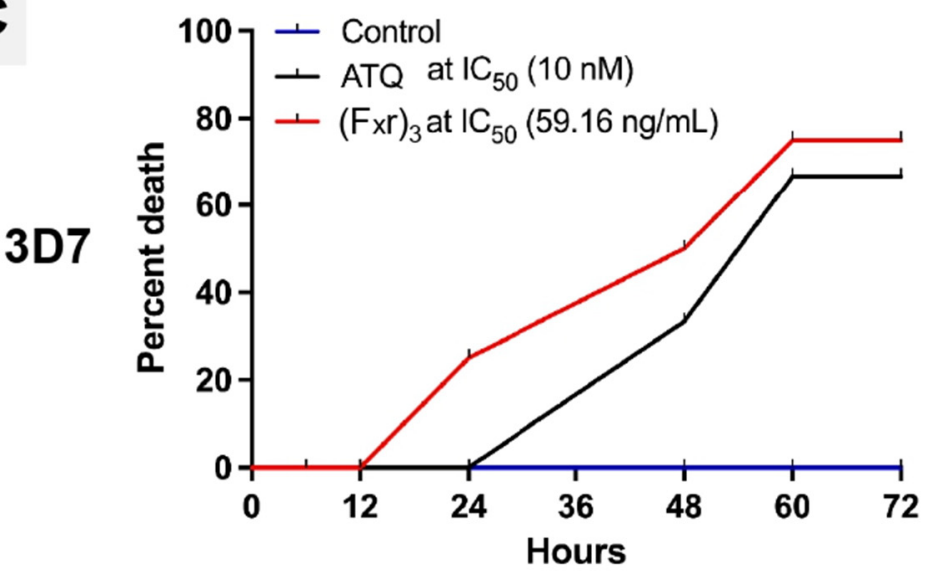

B

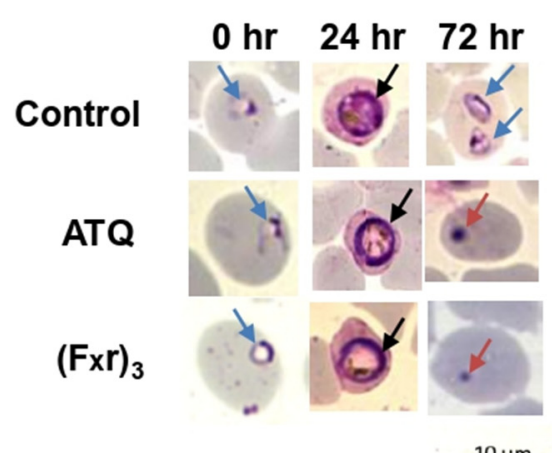

$10 \mu \mathrm{m}$

D

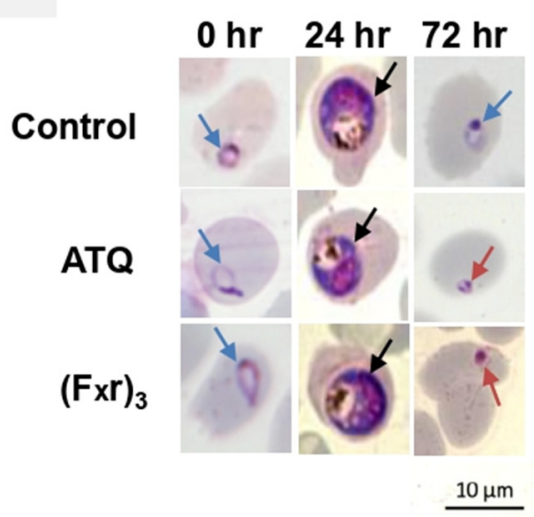

Figure 5. The percent death of strain K1 (A) and 3D7 (C) and Giemsa stain of strain K1 (B) and 3D7 (D) during incubation with $\left(\mathrm{F}_{\mathrm{X}} \mathrm{r}\right)_{3}$ and ATQ for $72 \mathrm{~h}$. Blue, black, and red arrows indicate ring, trophozoite and dead parasite, respectively.

\section{Discussion}

Malaria mitochondrion could be an attractive and selective target for the development of antimalarial drugs, as it plays a key role in energy production and is different from those of their vertebrate hosts. Even though the outer membrane of a mitochondrion is semi-permeable, allowing free access of small and large molecules up to $5 \mathrm{kDa}$, the inner membrane maintains a very tight barrier to the transport of many small and large molecules (including drugs) to the mitochondrial matrix [16]. Mitochondria-penetrating peptides or MPPs have been developed to accelerate the transport of molecules into the human mitochondrion [14]. MPPs can target and penetrate the mitochondria of active eukaryotic 
cells by two major properties, being cationic and lipophilic. These characteristics may explain the antiplasmodial activity of our peptide. In order to exploit MPPs as antimalarial agents, they must also be able to pass through the red blood cell membrane without disruption or destruction. After passing through this membrane, they must penetrate the parasite membrane and specifically target the mitochondria. However, mitochondria of malaria exhibit some extraordinary evolutionary and functional features, such as the membrane composition, which is different from that of eukaryotic cells [5]. Moreover, the mitochondrial characteristics of each stage of the parasite are different, so the ability of MPPs to act on parasite mitochondrion must be observed. In this study, a promising mitochondria-targeting peptide, known as (L-cyclohexyl alanine-D-arginine $)_{3}$ or $\left(\mathrm{F}_{\mathrm{x}} \mathrm{r}\right)_{3}$, was selected for elucidating the antimalarial activity of MPPs.

$\left(\mathrm{F}_{\mathrm{x}} \mathrm{r}\right)_{3}$ exhibited antimalarial activity against both chloroquine-sensitive (3D7) and resistant (K1) strains of P. falciparum with, notably, more effective antiplasmodial activity toward late-stage parasites as shown by $\mathrm{IC}_{50}$ values. This might be due to more active mitochondria in early-stage parasites. There was a report on the stage-specific presence of cristae inside P. falciparum mitochondrion. In ring-stage parasites, the mitochondrion is elongated, acristate with low electron density. In trophozoites, the mitochondrion is significantly larger with an unchanged appearance from that of the ring stage. In mature schizonts, each daughter merozoite harbors one small, acristate, electron-lucent mitochondrion in close proximity to one four-membrane-bound apicoplast [17]. There are discrepancies in the $\mathrm{IC}_{50}$ results between strains $\mathrm{K} 1$ and 3D7. The antimalarial drug susceptibility of both strains revealed that they showed different sensitivity to antimalarial drugs, including chloroquine, piperine, mefloquine and artesunate. Strain $\mathrm{K} 1$ is highly resistant to chloroquine $\left(\mathrm{IC}_{50}\right.$ is $115.0 \mathrm{nM}$ ), while strain $3 \mathrm{D} 7$ is very sensitive ( $\mathrm{IC}_{50}$ of $3.9 \mathrm{nM}$ ). In contrast, strain $\mathrm{K} 1$ exhibited lower sensitivity toward other antimalarial drugs such as piperine and artesunate. The $\mathrm{IC}_{50}$ of strains K1 and 3D7 against mefloquine were $4.22 \mathrm{nM}$ and $14.6 \mathrm{nM}$, respectively. The $\mathrm{IC}_{50}$ of strains $\mathrm{K} 1$ and 3D7 against artesunate were $1.06 \mathrm{nM}$ and $2.48 \mathrm{nM}$, respectively [18]. It has been noted that the lowest $\mathrm{IC}_{50}$ of $\left(\mathrm{F}_{\mathrm{x}} \mathrm{r}\right)_{3}$ toward chloroquine-resistant $P$. falciparum, $\mathrm{K} 1$ strain, was only $59.16 \mathrm{ng} / \mathrm{mL}$. The $\mathrm{IC}_{50}$ values are within the $\mathrm{nM}$ range and are comparable to the $\mathrm{IC}_{50}$ values of established drugs toward different laboratory and field-isolated strains of $P$. falciparum such as chloroquine $(9.8-744 \mathrm{nM})$ and artemisinin monomer $(6.6-42.5 \mathrm{nM})$ and their derivatives: dihydroartemisinin or DHA (2.09-14.8 nM) and artesunic acid or ARS $(0.82 \mathrm{nM})$ [19]. In general, it can be said that $\left(\mathrm{F}_{\mathrm{x}} \mathrm{r}\right)_{3}$ exhibits high antimalarial activities against chloroquine-resistant strains of $P$. falciparum.

The action of $\left(\mathrm{F}_{\mathrm{x}} \mathrm{r}\right)_{3}$ was confirmed by cellular localization at the mitochondria of living malaria parasites. $\left(\mathrm{F}_{\mathrm{x}} \mathrm{r}\right)_{3}$ exhibited efficient cellular uptake and specific mitochondrial localization in human cells such as HeLa and MRC-5 cells [14]. Late-stage parasites (trophozoite and schizont) displayed higher amounts of $\left(\mathrm{F}_{\mathrm{x}} \mathrm{r}\right)_{3}$ localized in mitochondria than did ring stage (early-stage), and this might be due to the large mitochondrion of trophozoite and schizont compared to that of the ring stage [17]. This was in accordance with the higher antimalarial activity of $\left(\mathrm{F}_{\mathbf{x}} \mathrm{r}\right)_{3}$ toward parasites observed in late-stage. The antimalarial action of $\left(\mathrm{F}_{\mathrm{x}} \mathrm{r}\right)_{3}$ might be similar to that of atovaquone (ATQ), which caused a collapse of mitochondrial membrane potential. ATQ targets cytochrome $b$, which plays a role in electron transport during mitochondrial respiration [20] and functions by inhibiting mitochondrial electron transport and depolarizing malarial mitochondria leading to cell damage and death, while showing no effect on mammalian mitochondrial membrane potential [5]. However, ATQ is expensive and subject to relatively facile development of resistance [21]. The target of $\left(\mathrm{F}_{\mathbf{x}} \mathrm{r}\right)_{3}$ in the parasite's mitochondrion is still unelucidated and needs to be identified in order to pave the way for the development of new antimalarial agents. MPPs have been widely applied for gene and drug delivery to mitochondria, especially in conjunction with anticancer drugs such as cisplatin [known as MPP-cisplatin conjugate (mtPt)], which can induce apoptosis by damaging mitochondrial DNA without damaging nuclear DNA and overcomes cisplatin resistance in cancer cells [22]. 
$\left(\mathrm{F}_{\mathrm{X}} \mathrm{r}\right)_{3}$ could be an alternative choice for development as an antimalarial drug attacking mitochondria or used in combination with ATQ. Antagonism between ATQ and antimalarial drugs (quinolines and artesunate) has been previously reported [23]. Additionally, atovaquone-proguanil or malarone is prescribed as a fixed-dose prophylactic agent for travelers in malaria-endemic areas and used for treating uncomplicated malaria [21]. The combination study of ATQ and $\left(\mathrm{F}_{\mathrm{x}} \mathrm{r}\right)_{3}$ will be further elucidated to identify a potential benefit of antimitochondrial effects. By comparing the death rate of parasites after different time intervals, $\left(\mathrm{F}_{\mathrm{x}} \mathrm{r}\right)_{3}$ was found to kill P. falciparum strain $\mathrm{K} 1$ more rapidly than did ATQ with significant differences at 24 and $48 \mathrm{~h}$. The combination of ATQ and $\left(\mathrm{F}_{\mathrm{x}} \mathrm{r}\right)_{3}$, focused on the same target, could rapidly kill parasites throughout their eukaryotic life cycle. There are reports of substantial genetic differentiation among mitochondrial genomes of $P$. vivax collected from different regions [24] and the difficulty in vitro culturing due to the low amounts and mixed stages of the parasite. Therefore, knowledge of the parasite's biology was far less than that of $P$. falciparum. However, the usefulness of $\left(\mathrm{F}_{\mathrm{x}} \mathrm{r}\right)_{3}$ as an anti-vivax agent still needs to be explored, as drugs with the same target (such as ATQ) can kill P. vivax with an $\mathrm{IC}_{50}$ value of $30 \mathrm{nM}$ [25].

As evaluated by cytotoxicity assays, $\left(\mathrm{F}_{\mathrm{x}} \mathrm{r}\right)_{3}$ showed very low toxicity toward normal mouse fibroblast L929 and human peripheral white blood cells at concentrations ranging from $1 \mathrm{ng} / \mathrm{mL}$ to $10 \mu \mathrm{g} / \mathrm{mL}$. Moreover, it did not exhibit any toxicity toward red blood cells. This might be due to the cationic and lyophilic characteristics of $\left(\mathrm{F}_{\mathrm{x}} \mathrm{r}\right)_{3}$ facilitating cellular uptake and permeation of the hydrophobic mitochondrial membrane without cytotoxic activity [14]. Even though $\left(\mathrm{F}_{\mathrm{x}} \mathrm{r}\right)_{3}$ at the highest concentration tested $(100 \mu \mathrm{g} / \mathrm{mL})$ exhibited cytotoxicity and hemolytic activity, this concentration was around one thousand times higher than that of antimalarial activity. Several studies found that MPPs have low toxicity both in vitro and in vivo [14,26,27], suggesting the applicability of MPPs as delivery vectors and/or bioactive compounds. Besides toxicity, the sensitivity of peptides to protease degradation is a critical concern. Hemolysis is a hallmark of malaria infection and can release proteases. Moreover, there are several proteases released from parasites/lysing host cells and present in plasma/serum. Fortunately, the sequence of $\left(\mathrm{F}_{\mathrm{x}} \mathrm{r}\right)_{3}$, which is composed of L-cyclohexylalanine and an artificial arginine residue, is not cleaved by endogenous protease [28].

Our results demonstrated that $\left(\mathrm{F}_{\mathrm{x}} \mathrm{r}\right)_{3}$ can pass through the red blood cell membrane without disruption or destruction, and subsequently kill the blood stage of P. falciparum. $\left(\mathrm{F}_{\mathrm{x}} \mathrm{r}\right)_{3}$ showed more potent antimalarial activity toward late-stage (trophozoite and schizont) parasites, consistent with high intensity of $\left(\mathrm{F}_{\mathrm{x}} \mathrm{r}\right)_{3}$ localized in the parasites' mitochondria observed by confocal microscopy. Moreover, $\left(\mathrm{F}_{\mathrm{x}} \mathrm{r}\right)_{3}$ exhibited high antimalarial activity against the chloroquine-resistant K1 strain of P. falciparum and showed very low toxicity toward normal mouse fibroblast L929 cells, human peripheral white blood cells (PBMCs) and red blood cells. To our knowledge, there is no study on the sensitivity and specificity of $\left(\mathrm{F}_{\mathrm{x}} \mathrm{r}\right)_{3}$ toward the malaria parasite, P. falciparum. This is the first report on the antimalarial activity of $\left(\mathrm{F}_{\mathrm{x}} \mathrm{r}\right)_{3} \cdot\left(\mathrm{F}_{\mathrm{x}} \mathrm{r}\right)_{3}$ or other MPPs might be developed as new antimalarial agents or used in combination with current antimalarial agents targeting the mitochondrion, such as atovaquone.

\section{Materials and Methods}

\subsection{Culture of Parasite}

Plasmodium falciparum strains 3D7 (CQ-sensitive clone), K1 (CQ-resistance clone) and two field-isolated strains (J1 and MR4) were used in this study. They were kindly provided by the Department of Parasitology, Phramongkutklao College of Medicine, Thailand. All isolate strains were continuously cultured using standard methods with modifications [29]. For parasite culture, human blood group $\mathrm{O}^{+} \mathrm{RBCs}$ were used, and white blood cells were removed by washing with RPMI 1640 . Complete culture medium was prepared by adding $10 \mathrm{~mL}$ of $0.5 \%$ albumax II (Invitrogen, Waltham, MA, USA) to each $200 \mathrm{~mL}$ aliquot of stock RPMI 1640 medium (Gibco URL, Waltham, MA, USA) containing 2.05 mM L-glutamine, 
$25 \mathrm{mM}$ HEPES, $21 \mathrm{mM}$ sodium bicarbonate and gentamycin $(5 \mathrm{~g} / \mathrm{mL})$. A $5 \%$ parasitemia and $5 \%$ hematocrit were maintained under $5 \% \mathrm{CO}_{2}, 3 \% \mathrm{O}_{2}$ and $92 \% \mathrm{~N} 2$ at $37{ }^{\circ} \mathrm{C}$. Five percent D-sorbitol (Sigma, St. Louis, MO, USA) was used for parasite synchronization by adding $10 \mathrm{~mL}$ of $5 \%$ D-sorbitol per $1 \mathrm{~mL}$ packed red cells and incubating at $37^{\circ} \mathrm{C}$ for $30 \mathrm{~min}$, and after that washing with RPMI1640 at $2000 \times g$ for $5 \mathrm{~min}$.

\subsection{Mitochondria-Penetrating Peptide}

A short peptide (L-cyclohexyl alanine-D-arginine $)_{3}$ or $\left(\mathrm{F}_{\mathrm{x}} \mathrm{r}\right)_{3}$, composed of alternating hydrophobic cyclohexylalanine $\left(\mathrm{F}_{\mathrm{x}}\right)$ and D-arginine $(\mathrm{r})$, was used as a mitochondriapenetrating peptide (MPP) in this study [14]. It was kindly provided by Professor Dr. Shana O. Kelley, University of Toronto, Canada. Synthesis of the peptide was performed by using solid-phase synthesis on Rink amide resin $(0.6-0.7 \mathrm{mmol} / \mathrm{g}, 100,200 \mathrm{mesh}$ (NovaBiochem, Darmstadt, Germany). The peptide was purified by reversed-phase highpressure liquid chromatography, and the purity was greater than or equal to $95 \%$. Liquid chromatography-mass spectrometry (LC-MS) coupled with electron-spray ionization was used to confirm the identity of the conjugate.

\subsection{Cytotoxicity Determination}

The cytotoxic activity of $\left(\mathrm{F}_{\mathrm{x}} \mathrm{r}\right)_{3}$ was assessed with the L929 mouse skin fibroblast cell line. Cells were cultured in RPMI 1640 medium with $10 \%$ fetal bovine serum, $2 \mathrm{mM}$ of L-glutamine, $100 \mathrm{U} / \mathrm{mL}$ of penicillin and $100 \mathrm{mg} / \mathrm{mL}$ of streptomycin at $37^{\circ} \mathrm{C}$. Cells were incubated at $37^{\circ} \mathrm{C}$ in a humidified incubator with $5 \% \mathrm{CO}_{2}$. Confluent cells were treated with $0.5 \%$ trypsin solution for detachment, diluted with $10 \%$ serum-containing medium. The cells were then plated in 96-well culture plates at 30,000 cells $/ \mathrm{cm}^{2}$. Culture plates were incubated for $24 \mathrm{~h}$ at $37^{\circ} \mathrm{C}$ in a humidified incubator with $5 \% \mathrm{CO} 2$ prior to stimulation of the cells with the compound. After that, L929 was incubated with ten-fold serial dilutions of $\left(\mathrm{F}_{\mathrm{x}} \mathrm{r}\right)_{3}$ with concentrations ranging from $0.1 \mathrm{ng} / \mathrm{mL}-100 \mu \mathrm{g} / \mathrm{mL}$. Viability of the cells was determined by 3-(4,5-dimethylthiazol-2-yl)-2,5-diphenyl tetrazolium or MTT assay. After removing the medium, cells were incubated with MTT solution $(5 \mathrm{mg} / \mathrm{mL}$ in PBS) for $4 \mathrm{~h}$ and the resulting formazan was solubilized with DMSO $(100 \mu \mathrm{L})$. Formazan absorbance was measured at $550 \mathrm{~nm}$ using an automated microplate reader. Cell viability was expressed as a percentage of the control culture value. Untreated cells and cells treated with $20 \%$ DMSO were used as negative and positive controls, respectively. All experiments were carried out in triplicate.

\subsection{Peripheral White Blood Cell Toxicity Assay}

Blood group O+ human PBMCs were isolated from fresh heparinized blood by Lymphoprep ( $\mathrm{r}=1.077 \mathrm{~g} / \mathrm{mL}$; Axis-Shield, Oslo, Norway). Lymphocytes were isolated from buffy coats by Lymphoprep followed by staining with Trypan Blue and number counting to determine cell survival (live and dead cells) with 96\% live cell. Human lymphocytes were conserved in RPMI 1640 medium until use, no longer than two weeks. Cells were plated on 96-well plates, 1000 cells per well, and co-incubated with ten-fold serial dilution of $\left(\mathrm{F}_{\mathrm{x}} \mathrm{r}\right)_{3}$ with concentrations ranging from $0.1 \mathrm{ng} / \mathrm{mL}-100 \mu \mathrm{g} / \mathrm{mL}$, at $37^{\circ} \mathrm{C}$ for $24 \mathrm{~h}$. Supernatants were collected after incubation, and the viability of the cells was determined by MTT assay as described above.

\subsection{Hemolytic Assay}

The human red blood cells (hRBCs) $(2 \% \mathrm{vol} / \mathrm{vol})$ were incubated with ten-fold serial dilutions of $\left(\mathrm{F}_{\mathrm{x}} \mathrm{r}\right)_{3}$ with concentrations ranging from $0.1 \mathrm{ng} / \mathrm{mL}-100 \mu \mathrm{g} / \mathrm{mL}$ at $37^{\circ} \mathrm{C}$ for $24 \mathrm{~h}$. Supernatants were collected after centrifugation at $2000 \times \mathrm{g}$ for $10 \mathrm{~min}$, and the absorbance was determined by spectrophotometry at $540 \mathrm{~nm}$ (Labomed Inc, Los Angeles, CA, USA). The values were converted to $\%$ hemolysis by comparing to the control $(100 \%$ hydrolysis) using distilled water (DW). 


\subsection{In Vitro Drug Sensitivity Assay}

Sensitivities of P. falciparum to $\left(\mathrm{F}_{\mathbf{x}} \mathrm{r}\right)_{3}$ and atovaquone (ATQ) were investigated based on the incorporation of $\left[{ }^{3} \mathrm{H}\right]$ hypoxanthine into parasite nucleic acids or radioisotopic technique [30]. The level of radioactivity uptake was used as the index of parasite growth. All strains were maintained in continuous culture at $5 \%$ parasite, $5 \%$ hematocrit using type $\mathrm{O}^{+}$human erythrocytes in RPMI 1640 with $0.5 \%$ Albumax (Invitrogen), $25 \mathrm{mM}$ HEPES (Sigma), under a $3 \% \mathrm{O}_{2}, 4 \% \mathrm{CO}_{2}$ and $93 \% \mathrm{~N} 2$ gas mixture. Parasites (1\% hematocrit) were incubated with ten-fold serial dilutions of $\left(\mathrm{F}_{\mathrm{x}} \mathrm{r}\right)_{3}$ or ATQ in the microtiter plate at $37^{\circ} \mathrm{C}$. At the end of the incubation period, the plates were removed from the chamber, and a final concentration of $50 \mu \mathrm{Ci}\left[{ }^{3} \mathrm{H}\right]$ hypoxanthine (NEN, Boston, MA, USA) was added to each well. The plates were gently agitated to ensure adequate mixing of the parasite/drug solutions with the radiolabeled hypoxanthine and thereafter placed back into the incubation chamber and gassed for $5 \mathrm{~min}$ prior to incubation at $37^{\circ} \mathrm{C}$ for $24 \mathrm{~h}$. After incubation, the assay plates were harvested onto filtermats (Wallac A printed Filltermats, Turku, Finland), using a Tomtec March III M semi-automatic harvester. The filtermats were subsequently removed from the harvester and dried at $60{ }^{\circ} \mathrm{C}$ in an oven prior to scintillation counting. Each dry filtermat was placed inside a plastic sample bag, and $1 \mathrm{~mL}$ of a Beta-plate Scint (Wallac, Turku, Finland) was added on top of it. The bag was then sealed before being heated in a 1495-021 Microsealer (Wallac, Finland). Each filtermat was placed in a cassette, and the radioactivity measured using a 1450 Micro-Beta Trilux liquid scintillation and luminescence counter (Wallac, Turku, Finland).

\section{7. $\left(F_{x} r\right)_{3}$ Localization}

The late stage of P. falciparum strain $\mathrm{K} 1$ was incubated with $\left(\mathrm{F}_{\mathbf{x}} \mathrm{r}\right)_{3}$ linked with TAMRA or TM- $\left(\mathrm{F}_{\mathrm{x}} \mathrm{r}\right)_{3}$ at concentration of the IC50 for $4 \mathrm{~h}$. Hoechst 3342 (Sigma, Ronkonkoma, NY, USA), at a final concentration of $10 \mu \mathrm{g} / \mathrm{mL}$, was added into the cultures in order to determine the live parasite cells. Mitotracker green (Cell Signalling, Danvers, MA, USA) was added to achieve a final concentration of $400 \mathrm{nM}$ and incubated for $30 \mathrm{~min}$ at $37^{\circ} \mathrm{C}$. Then, the cells were washed two times with PBS pH 7.4. Images were taken with confocal laser scanning (ZEISS LSM 700). The excitation wavelength for visualization for Hoechst 33,342 was $355 \mathrm{~nm}$, and emissions were collected at $461 \mathrm{nM}$. The excitation wavelength for visualization of the mitotracker green was $490 \mathrm{~nm}$, and emissions were collected at $516 \mathrm{nM}$. The excitation wavelength for visualization TAMRA or $\left(\mathrm{F}_{\mathrm{x}} \mathrm{r}\right)_{3}$ was $555 \mathrm{~nm}$, and emissions were collected at $580 \mathrm{nM}$.

\subsection{Data Analysis}

All experiments were performed in triplicate, and the results are presented as mean \pm standard deviation (SD). The data were analyzed by one-way analysis of variance (ANOVA) with GraphPad Prism version 5; $p$-value $<0.05$ was considered statistically significant.

Author Contributions: Conceptualization, S.S. and R.A.; methodology, S.S.; validation, R.A., S.S. and M.M.; formal analysis, S.S. and N.K.; investigation, S.S.; resources, M.M. and R.A.; data curation, S.S.; writing-original draft preparation, S.S., N.K. and R.A.; writing-review and editing, S.S. and R.A.; visualization, P.A. and W.H.; supervision, M.M. and R.A.; project administration, R.A.; funding acquisition, M.M. and R.A. All authors have read and agreed to the published version of the manuscript.

Funding: This work was funded by the Thailand Science Research and Innovation Fundamental Fund (TUFF13/2564) and Thammasat University Research Unit in Antimicrobial Agents and Application. Miss Sangdao Somsri was supported by a Research Assistant Ph.D. Grant, Thammasat University.

Institutional Review Board Statement: The study was conducted according to the guidelines of the Declaration of Helsinki and approved by the Ethical Committee of Research on Human Beings from Ramathibodi Hospital, Faculty of Medicine, Mahidol University, Thailand (MURA2014/400).

Informed Consent Statement: Informed consent was obtained from all subjects involved in the study. 
Data Availability Statement: Data is contained within the article. The underlying raw data are available from the corresponding author on request.

Acknowledgments: We would like to thank Shana O Kelley, University of Toronto, Canada for kindly providing mitochondria-penetrating peptide $\left(\left(\mathrm{F}_{\mathrm{x}} \mathrm{r}\right)_{3}\right)$, and Rachanee Udomsangpetch, Faculty of Medical Technology, Mahidol University, Thailand for guidance in malaria culture and mitochondrion staining. We would like to thank Arthur Brown, Faculty of Medical Technology, Mahidol University, Thailand, for providing language assistance.

Conflicts of Interest: The authors declare that they have no conflict of interest.

\section{References}

1. World Health Organization. The "World Malaria Report 2019" at a Glance. Available online: https://www.who.int/news-room/ feature-stories / detail/world-malaria-report-2019 (accessed on 10 October 2021).

2. Bartoloni, A.; Zammarchi, L. Clinical aspects of uncomplicated and severe malaria. Medit. J. Hematol. Inf. Dis. 2012, 4, e2012026. [CrossRef] [PubMed]

3. World Health Organization. Emergency Response to Artemisinin Resistance in the Greater Mekong Subregion: Regional Framework for Action 2013-2015; WHO: Geneva, Switzerland, 2013.

4. Hikosaka, K.; Watanabe, Y.; Kobayashi, F.; Waki, S.; Kita, K.; Tanabe, K. Highly conserved gene arrangement of the mitochondrial genomes of 23 Plasmodium species. Parasitol. Inter. 2011, 60, 175-180. [CrossRef]

5. Srivastava, I.K.; Rottenberg, H.; Vaidya, A.B. Atovaquone, a broad spectrum antiparasitic drug, collapses mitochondrial membrane potential in a malarial parasite. J. Biol. Chem. 1997, 272, 3961-3966. [CrossRef]

6. Nakato, H.; Vivancos, R.; Hunter, P.R. A systematic review and meta-analysis of the effectiveness and safety of atovaquone proguanil (Malarone) for chemoprophylaxis against malaria. J. Antimicrob. Chemother. 2007, 60, 929-936. [CrossRef]

7. Silva, A.F.; Torres, M.D.T.; Silva, L.S.; Alves, F.L.; Pinheiro, A.A.S.; Miranda, A.; Capurro, M.L.; Oliveira, V.X., Jr. New linear antiplasmodial peptides related to angiotensin II. Malar. J. 2015, 14, 1-10. [CrossRef]

8. Maciel, C.; Junior, V.X.D.; Fázio, M.A.; Nacif-Pimenta, R.; Miranda, A.; Pimenta, P.F.P.; Capurro, M.L. Anti-plasmodium activity of angiotensin II and related synthetic peptides. PLoS ONE 2008, 3, e3296. [CrossRef] [PubMed]

9. Stolze, S.C.; Deu, E.; Kaschani, F.; Li, N.; Florea, B.I.; Richau, K.H.; Colby, T.; Hoorn, R.A.L.; Overkleeft, H.S.; Bogyo, M.; et al. The antimalarial natural product symplostatin 4 is a nanomolar inhibitor of the food vacuole falcipains. Chem. Biol. 2012, 19, 1546-1555. [CrossRef] [PubMed]

10. Torrent, M.; Pulido, D.; Rivas, L.; Andreu, D. Antimicrobial peptide action on parasites. Curr. Drug Targets 2012, 13, 1138-1147. [CrossRef]

11. Vale, N.; Aguiar, L.; Gomes, P. Antimicrobial peptides: A new class of antimalarial drugs? Front. Pharmacol. 2014, 5, 275. [CrossRef]

12. Krugliak, M.; Feder, R.; Zolotarev, V.Y.; Gaidukov, L.; Dagan, A.; Ginsburg, H.; Mor, A. Antimalarial activities of dermaseptin S4 derivatives. Antimicrob. Agents Chemother. 2000, 44, 2442-2451. [CrossRef]

13. Bell, A.; Monaghan, P.; Page, A.P. Peptidyl-prolyl cis-trans isomerases (immunophilins) and their roles in parasite biochemistry, host-parasite interaction and antiparasitic drug action. Int. J. Parasitol. 2006, 36, 261-276. [CrossRef]

14. Horton, K.L.; Stewart, K.M.; Fonseca, S.B.; Guo, Q.; Kelley, S.O. Mitochondria-penetrating peptides. Chem. Biol. 2008, 15, 375-382. [CrossRef]

15. Marbella, L.E.; Cho, H.S.; Spence, M.M. Observing the translocation of a mitochondria-penetrating peptide with solid-state NMR. Biochim. Biophys. Acta Biomembr. 2013, 1828, 1674-1682. [CrossRef] [PubMed]

16. Benz, R. Permeation of hydrophilic solutes through mitochondrial outer membranes: Review on mitochondrial porins. Biochim. Biophys. Acta 1994, 1197, 167-196. [CrossRef]

17. Evers, F.; Cabrera-Orefice, A.; Elurbe, D.M.; Kea-te Lindert, M.; Boltryk, S.D.; Voss, T.S.; Huynen, M.A.; Brandt, U.; Kooij, T.W. Composition and stage dynamics of mitochondrial complexes in Plasmodium falciparum. Nat. Commun. 2021, 12, 1-17. [CrossRef]

18. Thiengsusuk, A.; Muhamad, P.; Chaijaroenkul, W.; Na-Bangchang, K. Antimalarial Activity of Piperine. J. Trop. Med. 2018, 2018, 1-7. [CrossRef] [PubMed]

19. Fröhlich, T.; Çapcı Karagöz, A.; Reiter, C.; Tsogoeva, S.B. Artemisinin-derived dimers: Potent antimalarial and anticancer agents. J. Med. Chem. 2016, 59, 7360-7388. [CrossRef]

20. Srivastava, I.K.; Morrisey, J.M.; Darrouzet, E.; Daldal, F.; Vaidya, A.B. Resistance mutations reveal the atovaquone-binding domain of cytochrome b in malaria parasites. Mol. Microbiol. 1999, 33, 704-711. [CrossRef] [PubMed]

21. Blasco, B.; Leroy, D.; Fidock, D.A. Antimalarial drug resistance: Linking Plasmodium falciparum parasite biology to the clinic. Nat. Med. 2017, 23, 917-928. [CrossRef]

22. Wisnovsky, S.P.; Wilson, J.J.; Radford, R.J.; Pereira, M.P.; Chan, M.R.; Laposa, R.R.; Lippard, S.J.; Kelley, S.O. Targeting mitochondrial DNA with a platinum-based anticancer agent. Chem. Biol. 2013, 20, 1323-1328. [CrossRef]

23. Canfield, C.J.; Pudney, M.; Gutteridge, W.E. Interactions of atovaquone with other antimalarial drugs against Plasmodium falciparum in vitro. Exp. Parasitol. 1995, 80, 373-381. [CrossRef] [PubMed] 
24. Taylor, J.E.; Pacheco, M.A.; Bacon, D.J.; Beg, M.A.; Machado, R.L.; Fairhurst, R.M.; Herrera, S.; Kim, J.; Menard, D.; Póvoa, M.M.; et al. The Evolutionary History of Plasmodium vivax as Inferred from Mitochondrial Genomes: Parasite Genetic Diversity in the Americas. Mol. Biol. Evol. 2013, 30, 2050-2064. [CrossRef]

25. Treiber, M.; Wernsdorfer, G.; Wiedermann, U.; Congpuong, K.; Sirichaisinthop, J.; Wernsdorfer, W.H. Sensitivity of Plasmodium vivax to chloroquine, mefloquine, artemisinin and atovaquone in north-western Thailand. Wien Klin. Wochenschr. 2011, 1, 20-25. [CrossRef] [PubMed]

26. Fonseca, S.B.; Pereira, M.P.; Mourtada, R.; Gronda, M.; Horton, K.L.; Hurren, R.; Minden, M.D.; Schimmer, A.D.; Kelley, S.D. Rerouting chlorambucil to mitochondria combats drug deactivation and resistance in cancer cells. Chem. Biol. 2011, 18, 445-453. [CrossRef]

27. Buondonno, I.; Gazzano, E.; Jean, S.R.; Audrito, V.; Kopecka, J.; Fanelli, M.; Salaroglio, I.C.; Costamagna, C.; Roato, I.; Mungo, E.; et al. Mitochondria-Targeted Doxorubicin: A New Therapeutic Strategy against Doxorubicin-Resistant Osteosarcoma. Mol. Cancer Ther. 2016, 15, 2640-2652. [CrossRef]

28. Kalafatovic, D.; Giralt, E. Cell-Penetrating Peptides: Design Strategies beyond Primary Structure and Amphipathicity. Molecules 2017, 22, 1929. [CrossRef]

29. Jensen, J.B.; Trager, W. Plasmodium falciparum in culture: Uuse of outdated erythrocytes and description of the candle jar method. J. Parasitol. 1977, 63, 883-886. [CrossRef] [PubMed]

30. Desjardins, R.E.; Canfield, C.J.; Haynes, J.D.; Chulay, J.D. Quantitative assessment of antimalarial activity in vitro by a semiautomated microdilution technique. Antimicrob. Agents Chemother. 1979, 16, 710-718. [CrossRef] [PubMed] 